\title{
ras p21 Protein Promotes Survival and Fiber Outgrowth of Cultured Embryonic Neurons
}

Gian Domenico Borasio, Jacob John, ${ }^{\dagger}$ Alfred Wittinghofer, ${ }^{+}$Yves-Alain Barde,* Michael Sendtner,* and Rolf Heumann*

*Max-Planck-Institut für Psychiatrie

Abteilung Neurochemie

D-8033 Martinsried

Federal Republic of Germany

† Max-Planck-Institut für medizinische Forschung

Abteilung Biophysik

D-6900 Heidelberg

Federal Republic of Germany

\section{Summary}

\begin{abstract}
Although evidence obtained with the PC12 cell line has suggested a role for the ras oncogene proteins in the signal transduction of nerve growth factor-mediated fiber outgrowth, little is known about the signal transduction mechanisms involved in the neuronal response to neurotrophic factors in nontransformed cells. We report here that the oncogene protein T24-ras, when introduced into the cytoplasm of freshly dissociated chick embryonic neurons, promotes the in vitro survival and neurite outgrowth of nerve growth factorresponsive dorsal root ganglion neurons, brain-derived neurotrophic factor-responsive nodose ganglion neurons, and ciliary neuronotrophic factor-responsive ciliary ganglion neurons. The proto-oncogene product c-Ha-ras also promotes neuronal survival, albeit less strongly. No effect could be observed with truncated counterparts of T24-ras and c-Ha-ras lacking the 23 C-terminal amino acids including the membrane-anchoring, palmityl-accepting cysteine. These results suggest a generalized involvement of ras or ras-like proteins in the intracellular signal transduction pathway for neurotrophic factors.
\end{abstract}

\section{Introduction}

Neurotrophic factors are proteins regulating neuronal survival during normal vertebrate development and maintenance of differentiated neuronal functions in the adult. One of the typical features of these proteins is their neuronal specificity. For example, nerve growth factor (NGF; Levi-Montalcini and Angeletti, 1968; Thoenen and Barde, 1980) acts on sympathetic and most neural crest-derived sensory neurons in the PNS and on basal forebrain cholinergic neurons in the CNS. Administration of NGF during normal development reduces normally occurring cell death in NGF-responsive neuronal populations (Hamburger et al., 1981; Oppenheim et al., 1982) and rescues axotomized, adult cholinergic neurons in the CNS (Hefti, 1986). Likewise, brain-derived neurotrophic factor (BDNF) regulates in vivo the survival of placode-derived sensory neurons, which are not responsive to NGF (Hofer and Barde,
1988). Several other purified proteins able to rescue neurons in vitro have been described, although hitherto their precise in vivo role is less clear (Barde, 1988). One such protein is ciliary neuronotrophic factor (CNTF; Manthorpe et al., 1982; Barbin et al., 1984): in culture, it keeps alive virtually all neurons dissociated from the chick ciliary ganglion at embryonic day 8 (E8).

The action of these factors is generally assumed to be mediated by interaction with specific cell surface receptors. In the case of NGF and BDNF, low- and high-affinity receptors have been described on responsive neurons (Sutter et al., 1979; Rodriguez-Tébar and Barde, 1988). NGF is known to be internalized by the nerve terminals and retrogradely transported in endocytotic vesicles back to the neuronal cell bodies (Thoenen and Barde, 1980). However, no information is yet available as to the nature of the signal transduction mechanism in neurons. The NGF receptor gene has recently been isolated and cloned (Johnson et al., 1986; Radeke et al., 1987), but a close analysis of the cytoplasmic domain of the membrane protein encoded by this gene does not reveal the presence of an ATP binding site, nor does this domain bear any resemblance with other known receptors, including, in particular, those possessing a protein kinase activity.

Studies with rat pheochromocytoma cells (PC12 cells; Greene and Tischler, 1976), which stop dividing and produce fibers in response to NGF, have indicated that NGF itself cannot be the intracellular cytoplasmic signal: introduction of NGF into the cytoplasm by fusion of PC12 cells with erythrocytes loaded with NGF (Heumann et al., 1981) or by injection of NGF into the cells using glass capillaries (Seeley et al., 1983) produced no biological effect. In addition, NGF-blocking antibodies introduced by the same methods were unable to block the fiber outgrowth activity of extracellularly added NGF. However, using these cells, recent evidence has suggested a role for the ras oncogene proteins in NGF signal transduction. The mammalian oncogenes Ha-ras, $\mathrm{Ki}$-ras, and $\mathrm{N}$-ras have been extensively studied for their role in cellular proliferation (for review see Barbacid, 1987). They encode three highly homologous proteins of the same molecular weight $(21 \mathrm{kd})$, which share structural and biochemical properties with the $\alpha$ subunits of guanine nucleotide binding regulatory proteins (G-proteins), in particular the binding and hydrolysis of GTP. Like NGF added extracellularly, microinjection of purified Ha-ras p21 protein (Bar-Sagi and Feramisco, 1985), as well as transfection of the $\mathrm{N}$-ras gene (Guerrero et al., 1986), or infection with Kirsten murine sarcoma virus (Noda et al., 1985) induced fiber outgrowth in PC12 cells. In addition, microinjected function-blocking antiras antibodies were able to prevent NGF-induced fiber outgrowth in PC12 cells (Hagag et al., 1986).

These findings obtained with a transformed cell line prompted us to investigate the effects of ras $\mathrm{p} 21$ proteins in primary cultures of embryonic neurons. These neu- 

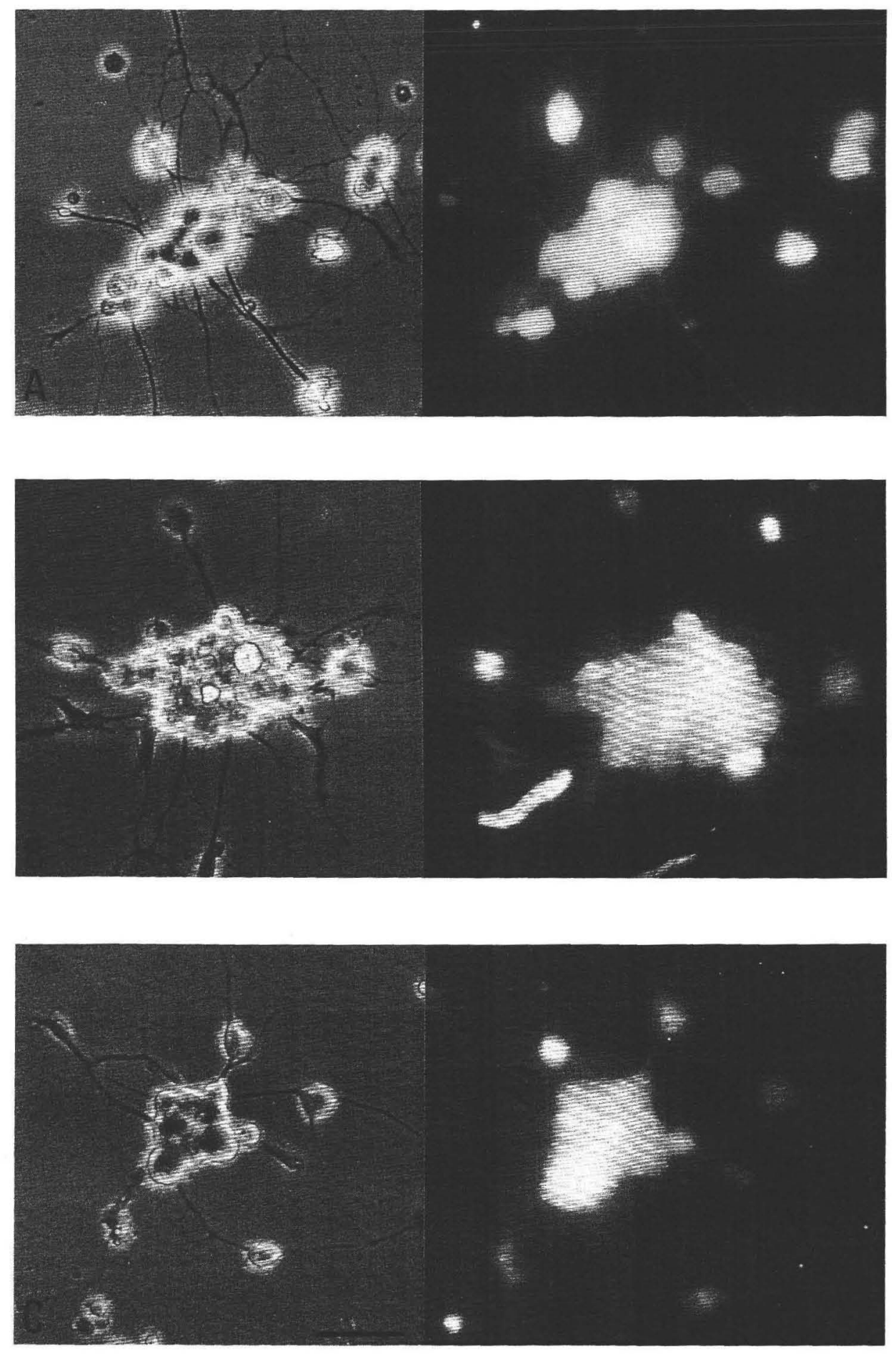

Figure 1. Phase and Fluorescence Micrographs of E9 DRG Neurons Triturated in the Presence of Various Rhodamine-Labeled ras p21 Preparations

(A) T24-ras at $3 \mathrm{mg} / \mathrm{ml}$; (B) T'-ras at $4.5 \mathrm{mg} / \mathrm{ml}$; (C) c-Ha-ras at $3 \mathrm{mg} / \mathrm{ml}$. The cells were cultured for $6 \mathrm{hr}$ in the presence of NGF (50 ng/ml). Note that the uptake efficiency and the degree of uptake variation between individual cells are comparable for all three proteins. Survival rates for cells from the same experiment cultured in the absence of NGF were established after $48 \mathrm{hr}$ : T24-ras, $42 \%$; T'-ras, $2.6 \%$; c-Ha-ras, $15 \%$. Bar, $50 \mu \mathrm{m}$ (phase); $40 \mu \mathrm{m}$ (fluorescence). 
rons, when grown isolated in culture, are dependent on the presence of exogenous proteins for survival and/or fiber outgrowth in vitro. We report here that ras p21 protein, when introduced into the cytoplasm of three different types of chick embryonic neurons, can promote their survival and fiber outgrowth, mimicking the in vitro effects of NGF, BDNF, and CNTF added extracellularly.

Results

\section{Cytoplasmic Delivery of ras by Trituration}

Preliminary experiments were performed using glass microcapillaries to inject the ras proteins into cultured nerve cells. However, although successful with PC12 cells, as reported by others (see Introduction), this technique proved unsuitable for the injection of a large number of neurons: many were irreversibly damaged by the injection procedure. We therefore turned to a different method, subsequently referred to as the trituration method, which is based on the scrape-loading method described by Ortiz et al. (1987). Briefly (see Experimental Procedures), ganglia were isolated from chick em. bryos, and after trypsinization, the ras proteins were in troduced into the cytoplasm of the neurons by merely exposing the cells to a high concentration of the protein $(2.5-25 \mathrm{mg} / \mathrm{ml})$ during mechanical dissociation. This procedure-trypsinization followed by mechanical dissociation - is known to involve mechanical damage of the plasma membrane (Sendtner et al., 1988), thus allowing for the uptake of proteins present in the surrounding medium. In most experiments, we used the bacterially expressed T24-ras protein $(2.5 \mathrm{mg} / \mathrm{ml})$, which exhibits a Gly-Val substitution at position 12 (Tabin et al. 1982; Tucker et al., 1986). As a control, cells were triturated in the presence of the same concentration of truncated versions of T24-ras and C-Ha-ras, lacking the 23 C-terminal amino acids. These truncated proteins, termed T'ras and c'ras, retain the same GTP binding and GTPase activity as their full-length counterparts (J. J. and A. W., unpublished data), but they lack the membraneanchoring, palmityl-accepting cysteine-186, which has been shown to be essential for the biological activity of ras p21 (Willumsen et al., 1984; Chen et al., 1985)

To determine the efficiency of the loading procedure directly, we covalently labeled T24-ras, T'-ras, and c-Haras with rhodamine (see Experimental Procedures). After trituration, virtually all neurons ( $>99 \%$ ) were found to be strongly fluorescent, indicating the uptake of the ras p21 proteins, irrespective of the neuronal population employed. Figure 1 shows the results obtained with embryonic dorsal root ganglion (DRG) neurons. The intracellular location of the fluorescent proteins was confirmed by confocal laser scanning microscopy (thickness of the optical section $<1 \mu \mathrm{m}$; Figure 2 ).

\section{Survival Effect of T24-ras and c-Ha-ras NGF-Responsive DRG Neurons}

Neural crest-derived sensory neurons from the DRG of chick embryos survive and extend processes in culture in the presence of NGF, whereas they die rapidly in its ab-

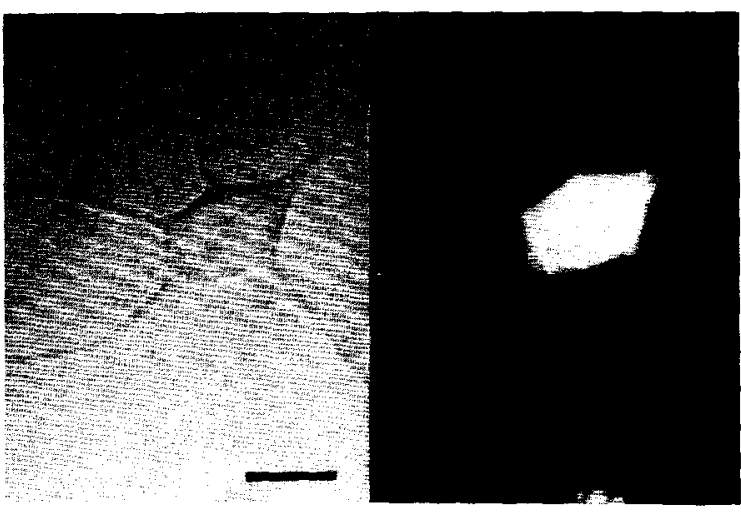

Figure 2. Chick Embryo Neuron Loaded by Trituration with Rhodamine-Coupled T24-ras, as Seen with a Bio-Rad Confocal Lase Scanning Microscope

The intracellular location of the ras protein is confirmed, since the thickness of the optical section visualized here is less than $1 \mu \mathrm{m}$. Bar, $25 \mu \mathrm{m}$

sence (Levi-Montalcini and Angeletti, 1963). We found that trituration of E9 DRG with T24-ras at a concentration of $2.5 \mathrm{mg} / \mathrm{ml}$ resulted in the survival of $44.0 \%$ of the neurons after 3 days (Figure $3 \mathrm{~A}$ ). This was about half of the NGF-induced survival $(91.3 \%)$. Trituration with $\mathrm{T}^{\prime}$-ras yielded a background survival value of $4.0 \%$ in the absence of NGF, in the range of the values obtained by trituration of the cells in buffer only $(4.4 \%$; data not shown). Under these conditions, most of the neurons initially present had obviously degenerated when examined after 2 days (Figure $4 \mathrm{E}$ ). In the presence of NGF, $\mathrm{T}^{\prime}$-ras-injected neurons showed a slightly reduced survival as compared with the effects of NGF on T24-rasinjected neurons $(79.5 \%$ versus $91.3 \%$ )

To establish whether the ras effect was dose-dependent, we triturated E9 DRG in the presence of increasing T24-ras concentrations (Figure 5A). Survival values increased proportionally with the log of the T24-ras concentration, and at $25 \mathrm{mg} / \mathrm{ml}$, maximal survival $(98 \%)$ was reached, similar to that obtained with NGF. Significantly, the proto-oncogene product p21 c-Ha-ras also promoted survival in a logarithmic dose-dependent fashion (Figure 5A). However, its effect was markedly lower than that of the T24-ras protein ( $24 \%$ survival at $30 \mathrm{mg} / \mathrm{ml}$ ). In addition, neurons triturated in the presence of $\mathrm{c}-\mathrm{Ha}$ ras or a low concentration $(0.25-0.8 \mathrm{mg} / \mathrm{ml})$ of T24-ras while surviving, exhibited a smaller cellular volume (Fig ure 4 ), as compared with cells triturated with high concentrations of T24-ras $(8-25 \mathrm{mg} / \mathrm{ml})$ or treated with NGF (Figures 4A, 4B, 4D, and 4F). Thus, high concentrations of T24-ras apparently can also mimic the known NGFinduced neuronal hypertrophy (Hendry, 1976).

The survival-promoting effect of T24-ras started to fade slowly after about 3 days (Figure $5 B$ ). Neurons triturated with T24-ras at a concentration of $8 \mathrm{mg} / \mathrm{ml}$ and cultured in the absence of NGF exhibited $75.7 \%$ of the NGF-induced survival at day $2,62.5 \%$ at day 5 , and $41.1 \%$ at day 9 . The values obtained with neurons tritu- 
A

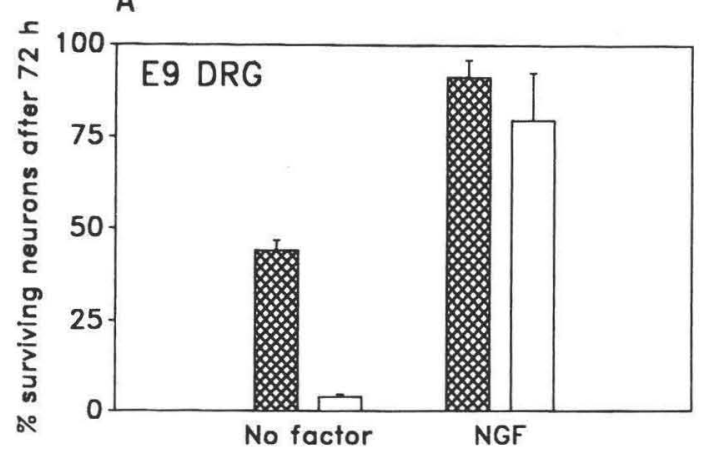

C

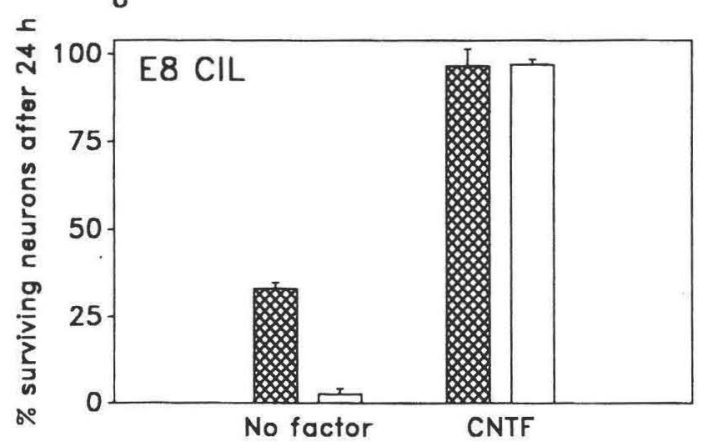

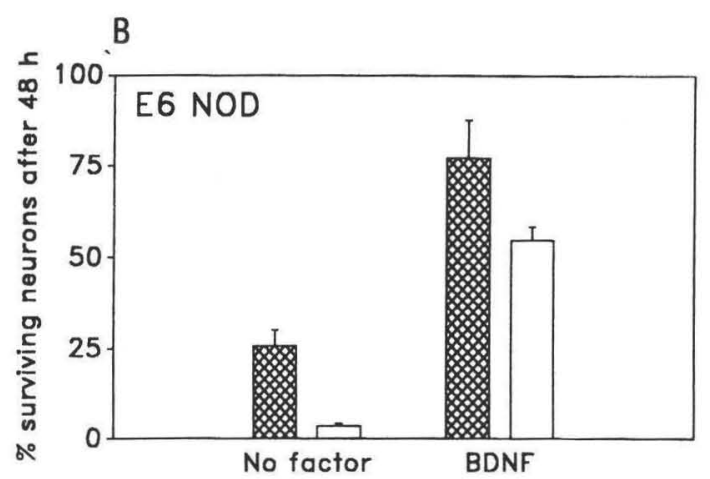

D

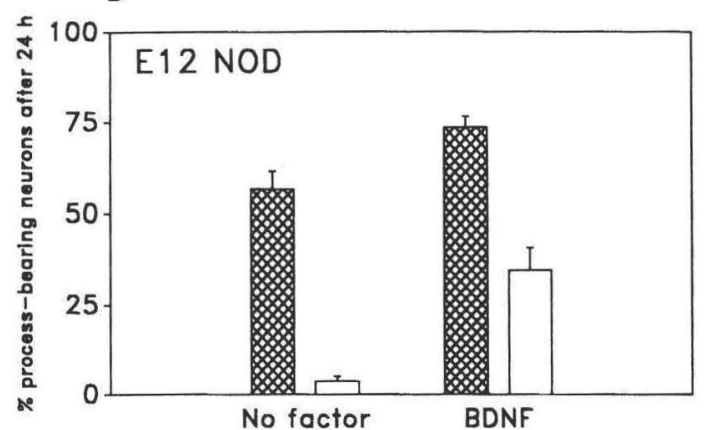

Figure 3. Neuronal Survival and Process Outgrowth in Dorsal Root, Ciliary, and Nodose Ganglia Following Trituration in the Presence of T24ras and Controls

Dorsal root, ciliary, and nodose ganglia were dissected at different embryonal ages and triturated in the presence of T24-ras (2.5 mg/ml, crosshatched bars) or T'-ras $(2.6 \mathrm{mg} / \mathrm{ml}$, blank bars). Neuronal survival was determined at the times indicated in both the absence and the presence of saturating concentrations of the respective factors. For E12 nodose ganglion neurons, the percentage of process-bearing neurons was determined after $24 \mathrm{hr}$. Repeat experiments were performed at least twice for each neuronal population, yielding essentially identical results regardless of the control protein used ( $T^{\prime}$-ras or $C^{\prime}$-ras). In the case of $\mathrm{E} 6$ nodose ganglion neurons, only two experiments were performed, using in both cases $C^{\prime}$-ras as the control protein. Data shown are means \pm SD of triplicate or quadruplicate determinations. (A) E9 DRG; (B) E6 nodose ganglia; (C) E8 ciliary ganglia; (D) E12 nodose ganglia.

rated in the presence of $2.5 \mathrm{mg} / \mathrm{ml} \mathrm{T24-ras} \mathrm{were} \mathrm{cor-}$ respondingly lower, i.e., $54.4 \%, 31.6 \%$, and $11.6 \%$ of the NGF-induced survival after 2, 5, and 9 days, respectively. BDNF-Responsive Nodose Ganglion Neurons

To determine whether the survival effects of T24-ras could also be observed in non-NGF-responsive neurons, we next used the placode-derived neurons of the nodose ganglia. It has recently been shown that, in birds, NGF has no survival effect on these neurons in vitro (Lindsay et al., 1985) or in vivo (Hofer and Barde, 1988). However, a substantial proportion of these neurons can be supported by BDNF, both in vitro and in vivo (Lindsay et al., 1985; Hofer and Barde, 1988). Trituration of E6 nodose ganglia in the presence of T24-ras at $2.5 \mathrm{mg} / \mathrm{ml}$ resulted in the survival of $25.8 \%$ of neurons after 2 days in culture in the absence of BDNF, compared with $3.5 \%$ in the presence of $C^{\prime}$-ras (Figure 3B). The T24-ras-treated cells were able to grow out processes under these conditions. However, fiber outgrowth was not as extensive as that seen with BDNF (Figures $6 \mathrm{~B}$ and $6 \mathrm{C}$ ).

It should be noted that, in the presence of BDNF, sur- vival of the T24-ras-injected neurons was markedly higher than that of the $\mathrm{T}^{\prime}$-ras-injected neurons $(77.1 \%$ versus $54.7 \%$; Figure $3 \mathrm{~B}$ ). The survival effect of T24-ras was reversible in a time-dependent fashion similar to that observed for DRG neurons (data not shown).

\section{CNTF-Responsive Ciliary Ganglion Neurons}

Parasympathetic neurons from the ciliary ganglia at E8 die very rapidly (within $24 \mathrm{hr}$ ) in culture unless the medium is supplemented with the purified protein CNTF (Barbin et al., 1984). These neurons are unable to survive in the presence of either NGF or BDNF. When triturated in the presence of T24-ras, 33\% of the neurons dissociated from E8 ganglia survived and grew neurites (Figure 3C; Figure 6E), compared with $2.5 \%$ with T'-ras. Survival in the presence of CNTF was about $97 \%$ for both populations.

\section{Neurite Outgrowth-Promoting Effect of ras p21}

To test whether activated ras p21 could induce neurite outgrowth independently of its survival-promoting activity, we used E12 nodose ganglion neurons as a model 

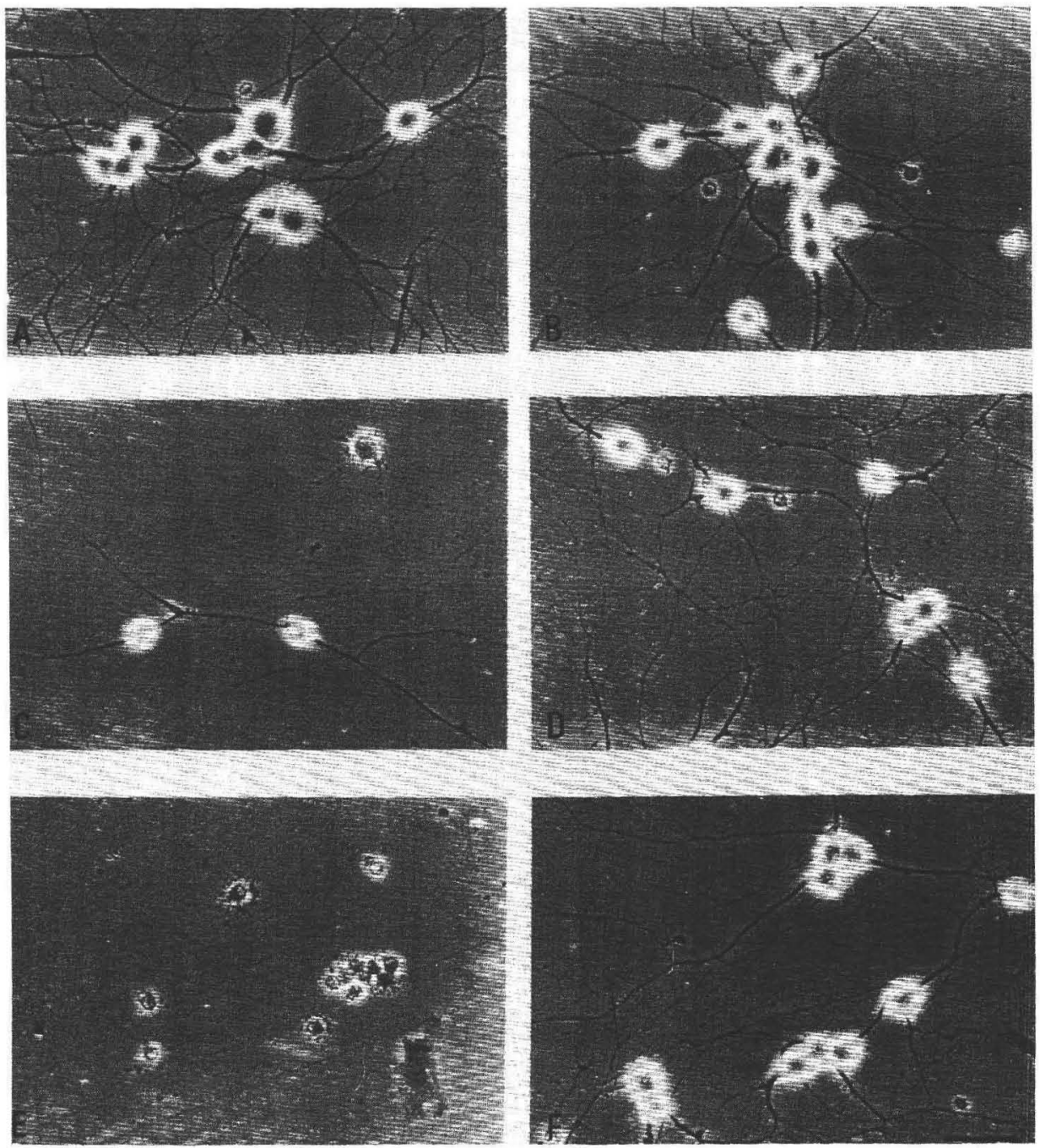

Figure 4. Phase-Contrast Micrographs of E9 DRG Neurons Triturated in the Presence of T24-ras, c-Ha-ras, or T'-ras

Protein concentrations were as follows: T24-ras, $25 \mathrm{mg} / \mathrm{ml}\left(\mathrm{A}\right.$ and $\mathrm{B}$ ); C-Ha-ras, $2 \mathrm{mg} / \mathrm{ml}\left(\mathrm{C}\right.$ and D); $\mathrm{T}^{\prime}$-ras, $2.6 \mathrm{mg} / \mathrm{ml}(\mathrm{E}$ and $\mathrm{F}$ ). Cells were cultured in either the absence (A, C, and E) or the presence (B, D, and F) of NGF $(20 \mathrm{ng} / \mathrm{ml})$ on laminin-coated culture dishes for 48 hr. In the case of T24-ras, the neurons appear identical regardless of the presence (B) or absence (A) of NGF. Note the difference in size between c-Ha-ras-injected neurons (C) and neurons injected with T24-ras and/or treated with NGF (A, B, D, and F). Bar, $50 \mu \mathrm{m}$.

system. At E12, the placode-derived sensory neurons of the nodose ganglion are no longer dependent on BDNF for survival in vitro, but they fail to extend neurites, even on laminin-coated dishes, when cultured in the absence of BDNF (Lindsay et al., 1985). Upon injection with T24ras, $56.6 \%$ of the cells exhibited marked neurite outgrowth (Figure 7B), which was morphologically indistinguishable from the BDNF effect. On the other hand, only $3.7 \%$ of the $T^{\prime}$-ras-injected cells showed neurite outgrowth under these conditions. The remaining T'-ras-injected cells were devoid of processes as shown in Figure 7A. BDNF-induced neurite outgrowth in the T24-rasinjected population was significantly and reproducibly higher than that in the T'ras-injected population $(73.5 \%$ versus $34.6 \%$ in the experiment shown, $P<0.02$, Student's $t$ test, two-tailed).

\section{Discussion}

Very little is presently known about the mechanisms transducing the neuronal survival effects of neurotrophic factors such as NGF. One important clue has been given by experiments performed on the NGFresponsive tumor line PC12: Bar-Sagi and Feramisco (1985) and Noda et al. (1985) have presented convincing evidence that the ras gene product $\mathrm{p} 21$, when microinjected into PC12 cells in its activated form, induces blockade of cell division and fiber outgrowth from these cells. In addition, injection of function-blocking antibodies to ras into these cells blocks the effects of NGF added extracellularly (Hagag et al., 1986). To test the effect of ras on neuronal primary cultures, we used a trituration method for the introduction of ras proteins into 


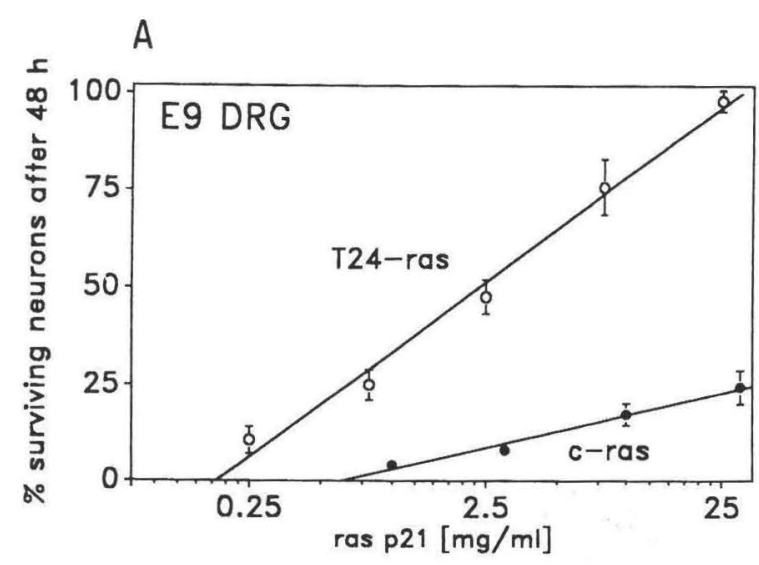

B

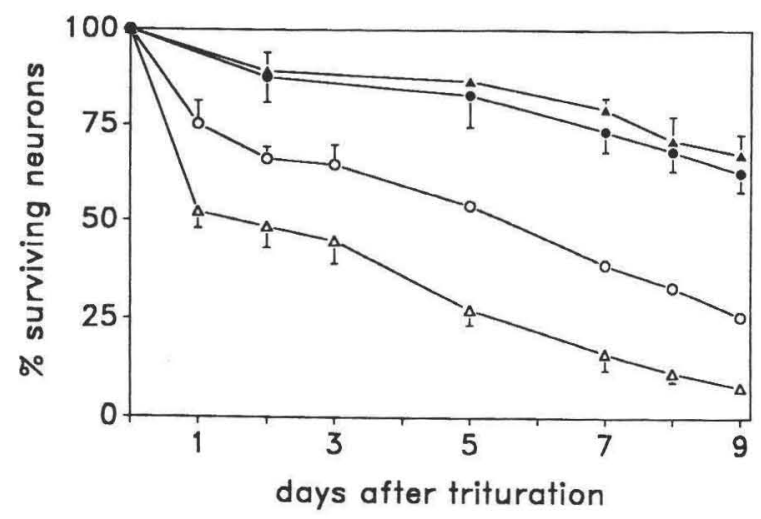

Figure 5. Dose-Response and Time Course Curves

(A) Dose-response curves for T24-ras and c-Ha-ras. E9 DRG were triturated as described in Experimental Procedures in the presence of increasing concentrations of T24-ras (open circles) and c-Ha-ras (filled circles). Neuronal survival was determined $48 \mathrm{hr}$ after plating. Final concentrations in the trituration solution were as follows: T24-ras, 0.25, 0.8, 2.5, 8, and $25 \mathrm{mg} / \mathrm{ml}$; c-Ha-ras, 1, 3, 10, and 30 $\mathrm{mg} / \mathrm{ml}$. All data shown are means \pm SD of triplicate or quadruplicate determinations.

(B) E9 DRG time course. E9 DRG were triturated in the presence of T24-ras at $8 \mathrm{mg} / \mathrm{ml}$ (circles) or $2.5 \mathrm{mg} / \mathrm{ml}$ (triangles). The cultures were maintained in either the absence (open symbols) or the presence (filled symbols) of NGF $(20 \mathrm{ng} / \mathrm{ml})$. All data shown are means \pm SD of triplicate determinations.

the neuronal cytoplasm, based on the scrape-loading procedure described by Ortiz et al. (1987). Using this technique, we could demonstrate a survival and neurite outgrowth-promoting effect of T24-ras in primary cultures of three different types of neurons responding to three different proteins, NGF, BDNF, and CNTF. These findings suggest that these neurons share a common, intracellular signal transduction mechanism resulting in survival and fiber outgrowth.

In the first series of experiments, we found that NGFresponsive DRG neurons could survive and grow out processes in the absence of NGF when loaded with T24ras. No such effects were seen using the C-terminally truncated counterparts $T^{\prime}$-ras and $c^{\prime}$-ras. This is most likely due to the expected inability of the $T^{\prime}$ and $c^{\prime}$ proteins to become acylated at the $\mathrm{C}$-terminus. Endogenous ras proteins are known to become palmitylated at a cysteine at position 186, which is deleted in $\mathrm{T}^{\prime}$-ras and $\mathrm{c}^{\prime}$-ras. This posttranslational step is essential for the membrane binding and transforming activity of ras p21 (Willumsen et al., 1984; Chen et al., 1985).

The effects of T24-ras were found to be strongly dosedependent. Almost complete survival, vigorous neurite outgrowth, and pronounced cellular hypertrophy could be observed with $25 \mathrm{mg} / \mathrm{ml} \mathrm{T24-ras} \mathrm{in} \mathrm{the} \mathrm{trituration} \mathrm{so-}$ lution. At this concentration, the ras-induced response cannot be distinguished from the effects of NGF on these cells. These data also indicate that practically all neurons in this system are capable of responding to microinjected ras p21. Since the cells exhibit a significant degree of variation in the uptake of exogenous ras protein (see Figure 1), it is likely that, with increasing ras concentrations, the proportion of neurons that have taken up the threshold amount of ras necessary for promoting survival increases. After 3 days, the response induced by ras in E9 DRG neurons started to fade slowly, presumably because of intracellular degradation of T24ras (Figure 5B). Importantly, the proto-oncogene C-Haras, although clearly less active than T24-ras, was also found to support the survival of DRG neurons in a dosedependent fashion (Figure 4C; Figure 5A), suggesting that endogenous, ras-like cellular proteins might mediate the effects of NGF. The difference between the effects of T24-ras and c-Ha-ras could reflect the known inherent difference in biological potency between the two proteins (Barbacid, 1987), since their uptake efficiencies with the trituration method appear to be very similar (see Figures $1 \mathrm{~A}$ and $1 \mathrm{C}$ ).

The results obtained with NGF-responsive neurons prompted us to test the possibility that BDNF-responsive neurons might also show factor-independent survival with T24-ras. This seemed all the more interesting, since recently the neuronal BDNF receptors have been defined in terms of their dissociation constants (RodriguezTébar and Barde, 1988): high-affinity $\left(K_{d} 10^{-11} \mathrm{M}\right)$ and low-affinity $\left(K_{d} 10^{-9} \mathrm{M}\right)$ receptors were found. These dissociation constants are essentially identical to those reported before for the neuronal NGF receptors (Sutter et al., 1979), and it has been speculated that a ras-like protein might participate in the interconversion from low- to high-affinity NGF receptors (Radeke et al., 1987). We found that in E6 placode-derived, BDNF-responsive sensory neurons from the nodose ganglia, T24-ras induced survival with neurite outgrowth to an extent consistent with the amount of T24-ras used $(2.5 \mathrm{mg} / \mathrm{ml}$; Figure $3 \mathrm{~B}$ ). In addition, T24-ras was found to promote survival-independent neurite outgrowth in E12 nodose ganglion neurons (Figure 3D). Interestingly, at E6 and E12, the effects of T24-ras plus BDNF were found to be higher than those obtained with BDNF alone at saturating concentrations (Figures $3 \mathrm{~B}$ and 3D; Lindsay et al., 1985). This could mean that T24-ras is able to mimic the action of other neurotrophic factors, in addition to 

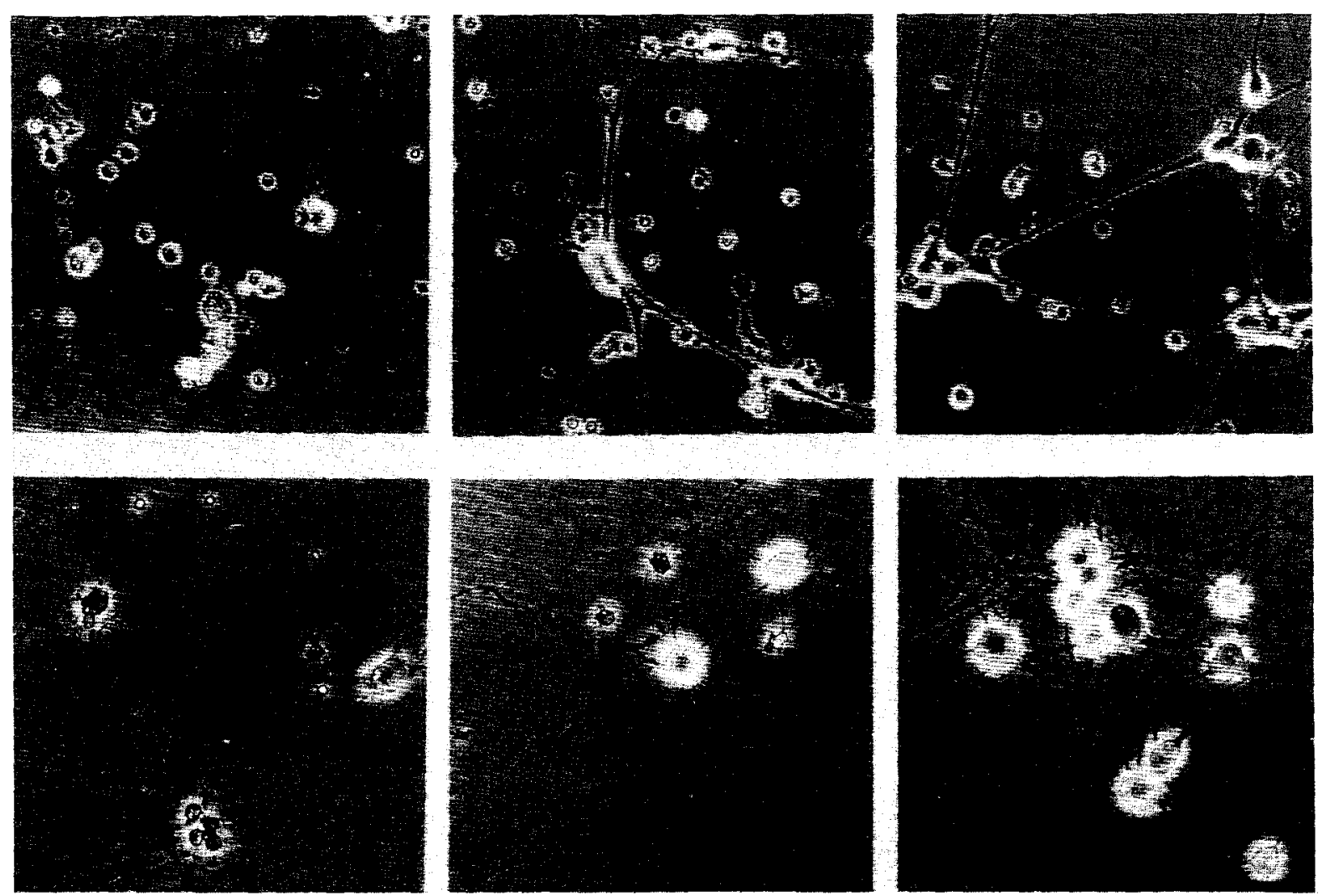

Figure 6. Phase-Contrast Micrographs of E6 Nodose Ganglion and E8 Ciliary Neurons Triturated in the Presence of T'ras or T24 ras

E6 nodose ganglion neurons $(A-C)$ and $E 8$ ciliary neurons $(D-F)$ were cultured on laminin-coated dishes. Cells were triturated in the presence of $T^{\prime}$-ras at $2.6 \mathrm{mg} / \mathrm{ml}(A, C, D$, and $F$ ) or T24-ras at $2.5 \mathrm{mg} / \mathrm{ml}(B$ and $E$ ) and cultured in either the absence (A, B, D, and E) or the presence $(C$ and $F$ ) of neurotrophic factor (BDNF or CNTF; $10 \mathrm{ng} / \mathrm{ml})$. After $48 \mathrm{hr}$ in culture $(24 \mathrm{hr}$ for ciliary neurons), only degenerating cells and cell remnants remained in T'-ras-injected control cultures (A and D). Bar, $50 \mu \mathrm{m}$.

BDNF, acting on nodose neurons such as the one contained in liver extracts (Lindsay and Rohrer, 1985). Finally, we used E8 parasympathetic neurons, known not to be supported in culture by NGF or BDNF, but by CNTF (Barbin et al., 1984). Again in this system, T24-ras induced survival and fiber outgrowth (Figure $3 \mathrm{C}$ ).

Why are such high concentrations of T24-ras needed to obtain a full survival effect in cultured neurons? One possible explanation is that, in addition to the need to escape proteolytic degradation (a general problem when introducing proteins into the cytoplasm), T24-ras expressed in E. coli is not palmitylated, but must be acylated to exert its biological activity. Presumably, as a result of these obstacles, only a small proportion of active T24-ras reaches its submembranous destination. Consistent with this interpretation is the observation that no fluorescence shift from the cytoplasm to the plasma membrane could be observed with the confocal laser scanning microscope in PC12 cells or neurons triturated with T24-ras coupled to rhodamine (Figure 2; unpublished data).

Thus, in summary, our results show that T24-ras introduced into the cytoplasm of embryonic neurons can replicate the typical biological activity of neurotrophic factors in vitro, namely survival and fiber outgrowth. It is tempting to speculate that ras or ras-like proteins are involved in the intracelfular transduction of signals initiated by the binding of various neurotrophic factors to their specific receptors. It is interesting to note in this context that the c-ras proto-oncogene products have been detected in a variety of neurons, both during development and in the adult (Furth et al., 1987).

\section{Experimental Procedures}

\section{Materials}

NGF and BDNF were purified as described by Hofer and Barde, (1988). CNTF was purified from adult rat sciatic nerve as described by Manthorpe et al. (1986). Plastic dishes for pre-plating were from Nunc, Wiesbaden, FRC. Petriperm dishes for final plating were from Heraeus. Pasteur pipettes were from Wu, Mainz. F14 medium was from GIBCO, horse serum was from Boehringer Mannheim, and laminin was from BRL. All other reagents were from Sigma.

Cell counting was performed on a Zeiss ICM 405 inverted micro scope using phase-contrast objectives with a high numerical opening as described below. Magnification was $320 x$.

\section{Cell Culture}

Chick embryonic DRG neurons (E9), ciliary ganglion neurons (E8), and nodose ganglion neurons ( $E 6$ and $E 12$ ) were isolated from the 

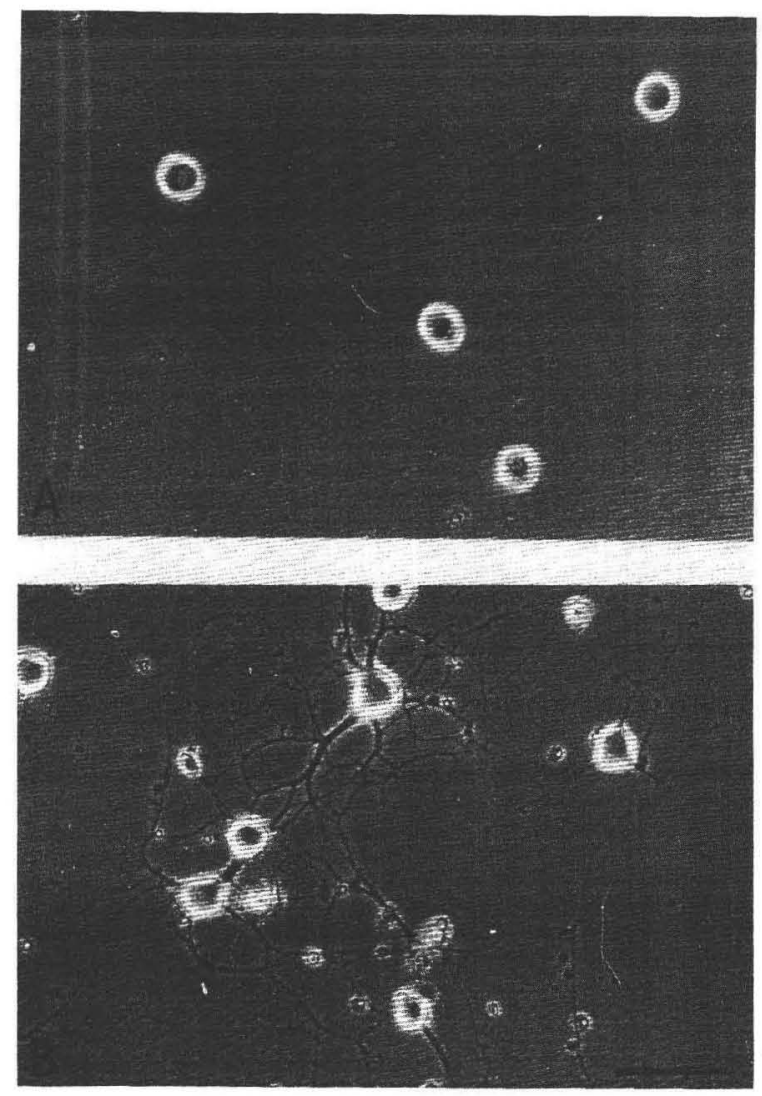

Figure 7. Phase-Contrast Micrographs of E12 Nodose Ganglion Neurons Triturated in the Presence of T'-ras or T24-ras

E12 nodose ganglion neurons were cultured for $24 \mathrm{hr}$ on laminincoated dishes. Neurons were triturated in the presence of T'-ras at $2.6 \mathrm{mg} / \mathrm{ml}$ (A) or T24-ras at $2.5 \mathrm{mg} / \mathrm{ml}$ (B). Note the phase-bright, nondegenerating neurons without processes in (A). Bar, $50 \mu \mathrm{m}$.

corresponding ganglia at the indicated ages and cultured using previously described methods (Lindsay et al., 1985; Hughes et al., 1988). After trypsinization and dissociation (see below), the cell suspension was pre-plated as described (Lindsay et al., 1985). The neuron-enriched cell suspensions were plated on Heraeus Petriperm dishes with Flexiperm divisions $(1.7 \mathrm{~cm}$ well diameter) that had been coated sequentially with poly-DL-ornithine $(1 \mathrm{mg} / \mathrm{ml})$ and laminin $(5 \mu \mathrm{g} / \mathrm{ml})$ as described for plastic dishes (Collins, 1978; Edgar et al., 1984). The cell density was approximately 5000 cells per $1.7 \mathrm{~cm}$ well. The bottom of the Petriperm dishes consists of a $20 \mu \mathrm{m}$ thick plastic foil. This allows the use of objectives with a high numerical opening and thus greatly enhances the fluorescence gain in the inverted microscope. No difference in neuronal survival or neurite outgrowth was observed as compared with the usual plastic tissue culture dishes, which were used for some of the repeat experiments.

Immediately after plating, survival factors were added to the appropriate wells at the following final concentrations: NGF, 20 $\mathrm{ng} / \mathrm{ml}$; BDNF, $10 \mathrm{ng} / \mathrm{ml}$; CNTF, $10 \mathrm{ng} / \mathrm{ml}$. The cultures were maintained with F14 medium containing $10 \%$ heat-inactivated horse serum (F14/HS) at $37^{\circ} \mathrm{C}$ and $3.5 \% \mathrm{CO}_{2}$ in a humidified environment.

One hour after plating, selected areas of each well, constituting approximately $10 \%$ of the well surface, which had been marked with a felt-tip pen prior to the laminin coating, were scanned for the presence of phase-bright cells. This procedure was repeated after 24-72 hr, depending on the neuronal types, to determine the survival rate. Thus, the survival rate is based on the number of cells that have survived the trituration procedure (see below). In the time course experiment, survival rates were repeatedly determined between $24 \mathrm{hr}$ and 9 days after trituration, as indicated in Figure 5B.

In the case of E12 nodose ganglion neurons, areas were scanned for the presence of phase-bright cells once, $24 \mathrm{hr}$ after plating. At the same time, the percentage of process-bearing neurons (neurite length $\geqslant 4 \times$ cell body diameter) was determined.

\section{Microinjection Procedure (Trituration Method)}

Direct microcapillary microinjection, used in preliminary experiments, was performed as described (Graessmann et al., 1980) using an Eppendorf/Zeiss microinjection system with pre-pulled capillaries. In all experiments shown, however, the molecules of interest were introduced into the cytoplasm by the following trituration method: ganglia were incubated for $30-45 \mathrm{~min}$ at $37^{\circ} \mathrm{C}$ with trypsin $\left(0.25 \%\right.$ in $\mathrm{Ca}^{2+} / \mathrm{Mg}^{2+}$-free PBS) and then washed with an excess of F14/HS medium. The ganglia were then centrifuged at $40 \times \mathrm{g}$ for $5 \mathrm{~min}$, and the medium was carefully removed until only 5-10 $\mu$ was left. A highly concentrated solution of the macromolecule to be injected $(20-30 \mu \mathrm{l})$ was then added, and the ganglia were dissociated (triturated) by slowly flushing the whole solution (total volume 25-40 $\mu$ l) 20 times through a siliconized Pasteur pipette (1.1 $\mathrm{mm}$ inner diameter) held at the bottom of a $1.5 \mathrm{ml}$ Eppendorf tube. As described (McCarthy and Partlow, 1976; Brundin et al., 1985), mechanical dissociation procedures create membrane damage to the neurons (see also Sendtner et al., 1988), but we found that more than $30 \%$ of the DRG neurons (based on an estimated average of 10,000 neurons per E9 DRG) survived this treatment. The neurons could be rescued by NGF, BDNF, or CNTF and maintained in culture for several days. Thus, the mechanical damage experienced by the cells, while allowing for the introduction of substantial amounts of exogenous protein into the cytoplasm, did not dramatically impair cell viability. However, this procedure tends to introduce a bias toward smaller neurons: in the DRG experiments (Figure 3A; Figure $5 B$ ), the proportion of neurons surviving with NGF alone is higher than that reported under identical culture conditions, after a milder dissociation procedure (Lindsay et al., 1985; Acheson et al., 1987). In the DRG, smaller, NGF-responsive neurons are probably selected at the expense of larger, BDNF-responsive neurons, including presumably the proprioceptive neurons known to respond to BDNF (Davies et al., 1986). In the other ganglia studied (nodose and ciliary), the spectrum of neuronal diameters is narrower than that in the DRG, and in accord with this, the survival data obtained with either BDNF or CNTF are identical to those reported earlier (Lindsay et al., 1985; Hughes et al., 1988).

The efficiency of the trituration procedure for neurons was monitored by trituration with rhodamine-labeled ras p21 protein (Figure 1). Injection frequency approached $100 \%$ in all cell populations studied, irrespective of the ras protein used. The intracellular localization of the fluorescent protein was established with the help of a Bio-Rad confocal laser scanning microscope (Figure 2).

After trituration, $1.3 \mathrm{ml}$ of $\mathrm{F} 14 / \mathrm{HS}$ was added to the solution and the cell suspension was centrifuged for $10 \mathrm{~min}$ at $100 \times \mathrm{g}$. The medium was again removed almost completely, and $1.3 \mathrm{ml}$ of fresh medium was added to the cell pellet. This second centrifugation step was performed to remove uninjected material from the culture medium. The cells were then carefully resuspended and pre-plated as described above.

\section{ras p21: Purification and Rhodamine Labeling}

The ras p 21 proteins used here (c-Ha-ras, its derivative T24-ras, and their truncated versions T'ras and c'ras) were produced in E. coli and purified basically as described (Tucker et al., 1986). The truncated versions of T24-ras and c-Ha-ras were obtained by inserting a stop codon (UAA) in place of the lysine 167 codon (AAA) (J. J. and A. W., unpublished data). Coupling of ras $\mathrm{p} 21$ to rhodamine isothiocyanate was performed as follows: $5-10 \mathrm{mg} / \mathrm{ml} \mathrm{p} 21$ (dissolved in $50 \mathrm{mM}$ EPPS-sodium [ $\mathrm{pH}$ 8.13] [Sigma], $5 \mathrm{mM} \mathrm{MgCl}, 1 \mathrm{mM}$ dithioerythreitol) were allowed to react with $20 \mu \mathrm{g} / \mathrm{ml}$ rhodamine isothiocyanate (stock solution $1 \mathrm{mg} / \mathrm{ml}$ in acetone) for $5 \mathrm{hr}$ at $4^{\circ} \mathrm{C}$. To remove the uncoupled dye, the reaction mixture was then filtrated twice through a PD10 pre-packed gel filtration column (Pharmacia) equilibrated with standard p21 buffer B $(64 \mathrm{mM}$ Tris, $50 \mathrm{mM} \mathrm{HCl}$, 
$10 \mathrm{mM} \mathrm{MgCl} 2,0.5 \mathrm{mM}$ dithioerythreitol [pH 7.6]) at $4^{\circ} \mathrm{C}$ (Tucker et al., 1986). This buffer was also used for dilution of the protein when necessary. The free rhodamine was seen to react with the column material during the first round of filtration; no uncoupled dye could be detected during the second chromatography. Notably, the rhodamine-labeled ras p21-preparations retained the same biological activity as their unlabeled counterparts, as described in Figure 1.

\section{PC12 Control Experiments}

The biological activity of the proteins injected using the trituration method was first established in PC12 cells. We found that, when introduced by the trituration method into PC12 cells, T24-ras at 2.5 $\mathrm{mg} / \mathrm{ml}$ induced $25 \%$ of the cells to grow out neurites (see also BarSagi and Feramisco, 1985). T'ras and c'ras were found to be totally devoid of biological activity in PC12 cells, while c-Ha-ras at $2 \mathrm{mg} / \mathrm{ml}$ caused $4 \%$ of the cells to produce fibers (data not shown)

\section{Acknowledgments}

We thank C. Krieger and E. Braun for excellent technical assistance, M. M. Hofer and H. Rohrer for helpful discussions, P. Carroll for revision of the manuscript, and K. C. Holmes for support. We are in debted to Hans Thoenen for his support and many useful suggestions. This work was supported by the Deutsche Forschungsgemeinschaft.

Received September 22, 1988; revised November 29, 1988.

\section{References}

Acheson, A., Barde, Y.-A., and Thoenen, H. (1987). High $\mathrm{K}^{+}-$mediated survival of spinal sensory neurons depends on developmental stage. Exp. Cell Res. 170, 56-63.

Barbacid, M. (1987). Ras genes. Annu. Rev. Biochem. 56, 779-827. Barbin, G., Manthorpe, M., and Varon, S. (1984). Purification of the chick eye ciliary neuronotrophic factor. J. Neurochem. 43, 1468-1478.

Barde, Y.-A. (1988). What, if anything, is a neurotrophic factor? Trends Neurosci. 11, 343-346.

Bar-Sagi, D, and Feramisco, J. R. (1985). Microinjection of the ras oncogene protein into $\mathrm{PC} 12$ cells induces morphological differentiation. Cell 42, 841-848.

Brundin, P., Isacson, O., and Björklund, A. (1985). Monitoring of cell viability in suspensions of embryonic CNS tissue and its use as a criterion for intracerebral graft survival. Brain Res. 331, 251-259. Chen, Z.-Q., Ulsh, L. S., DuBois, G., and Shih, T. Y. (1985). Posttranslational processing of $\mathrm{p} 21$ ras proteins involves palmitylation of the C-terminal tetrapeptide containing cysteine-186. J. Virol. 56 , $607-612$.

Collins, F. (1978). Axon initiation by ciliary neurons in culture. Dev. Biol. 65, 50-57.

Davies, A. M., Thoenen, H., and Barde, Y.-A. (1986). Different factors from the central nervous system and periphery regulate the survival of sensory neurones. Nature 319, 497-499.

Edgar, D., Timpl, R., and Thoenen, H. (1984). The heparin-binding domain of laminin is responsible for its effects on neurite outgrowth and neuronal survival. EMBO J. 3, 1463-1468.

Furth, M. E., Aldrich, T. H., and Cordon-Cardo, C. (1987). Expression of ras proto-oncogene proteins in normal human tissues. Oncogene $1,47-58$.

Graessmann, A., Graessmann, M., and Mueller, C. (1980). Microinjection of early SV40 DNA fragments and T antigen. Meth. Enzymol. 65, 816-825.

Greene, L. A., and Tischler, A. S. (1976). Establishment of a noradrenergic clonal cell line of rat adrenal pheochromocytoma cells which respond to nerve growth factor. Proc. Natl. Acad. Sci. USA 73, 2424-2428.

Guerrero, I., Wong, H., Pellicer, A., and Burstein, D. E. (1986). Acti- vated N-ras gene induces neuronal differentiation of PC12 rat pheochromocytoma cells. J. Cell. Physiol. 129, 71-76.

Hagag, N., Halegoua, S., and Viola, M. (1986). Inhibition of growth factor-induced differentiation of PC12 cells by microinjection of antibody to ras p21. Nature 319,680-682.

Hamburger, V., Brunso-Bechtold, J. K., and Yip, J. W. (1981). Neuronal death in the spinal ganglia of the chick embryo and its reduction by nerve growth factor. ). Neurosci. 1, 60-71.

Hefti, F. (1986). Nerve growth factor promotes survival of septal cholinergic neurons after fimbrial transections. J. Neurosci. 6 , 2155-2162.

Hendry, 1. A. (1976). A method to correct adequately for the change in neuronal size when estimating neuronal numbers after nerve growth factor treatment. ). Neurocytol. 5, 337-349.

Heumann, R., Schwab, M. E., and Thoenen, H. (1981). A second messenger required for nerve growth factor biological activity? $\mathrm{Na}$ ture 292, 838-840.

Hofer, M. M., and Barde, Y.-A. (1988). Brain-derived neurotrophic factor prevents neuronal death in vivo. Nature 331, 261-262.

Hughes, S. M., Lillien, L. E., Raff, M. C., Rohrer, H., and Sendtner, $M$. (1988). Ciliary neurotrophic factor induces type-2 astrocyte differentiation in culture. Nature 335, 70-73.

Johnson, D., Lanahan, A., Buck, C. R., Sehgal, A., Morgan, C., Mercer, E., Bothwell, M., and Chao, M. (1986). Expression and structure of the human NGF receptor. Cell 47, 545-554.

Levi-Montalcini, R., and Angeletti, P. U. (1963). Essential role of the nerve growth factor on the survival and maintenance of dissociated sensory and sympathetic neurons in vitro. Dev. Biol. 7, 653-659. Levi-Montalcini, R., and Angeletti, P. U. (1968). Nerve growth fac tor. Physiol. Rev. 48, 534-569.

Lindsay, R. M., and Rohrer, H. (1985). Placodal sensory neurons in culture. Nodose ganglion neurons are unresponsive to NGF, lack NGF receptors but are supported by a liver-derived neurotrophic factor. Dev. Biol. 112, 30-48.

Lindsay, R. M., Thoenen, H., and Barde, Y.A. (1985). Placode and neural crest-derived sensory neurons are responsive at early de velopmental stages to brain-derived neurotrophic factor. Dev. Biol $112,319-328$.

Manthorpe, M., Barbin, G., and Varon, S. (1982). Isoelectric focussing of the chick eye ciliary neuronotrophic factor. J. Neurosci. Res. 8, 233-239.

Manthorpe, M., Skaper, S. D., Williams, L. R., and Varon, S. (1986). Purification of adult rat sciatic nerve ciliary neuronotrophic factor Brain Res. 367, 282-286.

McCarthy, K. D., and Partlow, L. M. (1976). Preparation of pure neuronal and non-neuronal cultures from embryonic chick sympathetic ganglia: a new method based on both differential cell adhesiveness and the formation of homotypic neuronal aggregates. Brain Res. 114, 391-414.

Noda, M., Ko, M., Ogura, A., Liu, D., Amano, T., Takano, T., and Ikawa, Y. (1985). Sarcoma viruses carrying ras oncogenes induce differentiation-associated properties in a neuronal cell line. Nature $318,73-75$.

Oppenheim, R. W., Maderdrut, J. L., and Wells, D. J. (1982). Cell death of motoneurons in the chick embryo spinal cord. VI. Reduction of naturally occurring cell death in the thoraco-lumbar column of Terni by nerve growth factor. J. Comp. Neurol. 210, 174-189. Ortiz, D., Baldwin, M. M., and Lucas, J. J. (1987). Transient correction of genetic defects in cultured animal cells by introduction of functional proteins. Mol. Cell. Biol. 7, 3012-3017.

Radeke, M. J., Misko, T. P., Hsu, C., Herzenberg, L. A., and Shooter, E. M. (1987). Gene transfer and molecular cloning of the rat nerve growth factor receptor. Nature 325, 593-597.

Rodriguez-Tébar, A., and Barde, Y:A. (1988). Binding characteristics of brain-derived neurotrophic factor to its receptor on neurons from the chick embryo. J. Neurosci. 8, 3337-3342.

Seeley, P. J., Keith, C. H., Shelanski, M. L., and Greene, L. A. (1983). Pressure microinjection of nerve growth factor and anti- 
nerve growth factor into the nucleus and cytoplasm: lack of effects on neurite outgrowth from pheochromocytoma cells. J. Neurosci. 3, 1488-1494.

Sendtner, M., Gnahn, H., Wakade, A., and Thoenen, H. (1988). Is activation of the $\mathrm{Na}^{+} \mathrm{K}^{+}$pump necessary for NGF-mediated neuronal survival? f. Neurosci. 8, 458-462.

Sutter, A., Riopelle, R. J., Harris-Warrick, R. M., and Shooter, E. M. (1979). Nerve growth factor receptors. Characterization of two dis tinct classes of binding sites on chick embryo sensory ganglia cells. J. Biol. Chem. 254, 5972-5982.

Tabin, J. C., Bradley, S. M., Bargmann, C. I., Weinberg, R. A. Papageorge, A. G., Scolnick, E. M., Dhar, R., Lowy, D. R., and Chang, E. H. (1982). Mechanism of activation of a human oncogene. Nature 300, 143-152.

Thoenen, $H_{\text {., }}$ and Barde, $Y_{\text {A.A. }}$ (1980). Physiology of nerve growth factor. Physiol. Rev. 60, 1284-1335

Tucker, J., Sczakiel, G., Feuerstein, J., John, J., Goody, R. S., and Wittinghofer, A. (1986). Expression of p21 proteins in Escherichia coli and stereochemistry of the nucleotide-binding site. EMBO J. 5 , $1351-1358$.

Willumsen, B. M., Norris, K., Papageorge, A. G., Hubbert, N. L. and Lowy, D. R. (1984). Harvey murine sarcoma virus $\mathrm{p} 21$ ras protein: biological and biochemical significance of the cysteine nearest the carboxyl terminus. EMBO J. 3, 2581-2585 